\title{
Recent Advances on anti-MRSA Natural Products Derived from Plants
}

\author{
Jing Guo, ${ }^{a}$ Xiaoyu Su, ${ }^{a}$ Tianfang Ma, ${ }^{a}$ and Jifeng Liu* ${ }^{*, a, b}$ \\ ${ }^{a}$ School of Pharmaceutical Science, Zhengzhou University, Zhengzhou, Henan 450001, China \\ ${ }^{b}$ Collaborative Innovation Center of New Drug Research and Safety Evaluation, Zhengzhou, Henan 450001, \\ China
}

\author{
Email: Liujf2009y@126.com (J. L.)
}

\begin{abstract}
Methicillin-resistant Staphylococcus aureus (MRSA) is a multi-drug resistant pathogenic bacteria, which has seriously threatened human health for a long time. Therefore, there is an urgent and unmet demand for new types of antibiotics. In response to the antibiotic resistance, many researchers have studied natural products derived from plant for alternative antibiotics and therapies. In this review, we summarized recent advances on anti-MRSA natural products from plants and their potential antibacterial effect against MRSA as potential anti-MRSA agents since 2007.
\end{abstract}

Keywords anti-MRSA activity, natural products, phytochemistry, medicinal chemistry

\section{Introduction}

Staphylococcus aureus is a gram-positive bacterium that is notable for the frequency and severity of infections. It can cause purulent wound infection, tonsillitis, pneumonia, osteomyelitis, bacteremia and septic shock. ${ }^{[1,2]}$ Antibiotic resistance of $S$. aureus was almost unknown when the antibiotics, such as penicillin and streptomycin, were widely used in the 1940s. ${ }^{[3]}$ However, nowadays, $S$. aureus has become resistant to many commonly used antibiotics, especially methicillin-resistant $S$. aureus (MRSA), which possesses a serious public health threat. ${ }^{[4]}$ Numbers of clinical MRSA isolates are resistant not only to $\beta$-lactams, but also to vancomycin, linezolid, and other relatively new agents such as daptomycin. ${ }^{[5]}$ Therefore, much attention has been paid to the search for new anti-microbial agents for successful treatment of infections caused by MRSA. During the past ten years, many researchers have studied for alternative antibiotics and therapies from natural products. In this minireview, anti-MRSA substances isolated from plant sources, with their potential antibacterial effect against MRSA as potential anti-MRSA agents, are summarized according to their different chemical classes: alkaloids, terpenoids, flavonoids, et al. In addition, we discuss their chemical structures, traditional uses and sources.

\section{Alkaloids}

Alkaloids are organic nitrogenous base and have been used in medicine since ancient times. Many studies through the years have shown that alkaloids derived from plants exhibited anti-MRSA activity (Figure 1). A study conducted by Sun et al. examined the active constituents in Holarrhena antidysenteriaca. ${ }^{[6]}$ Two steroidal alkaloids, $\mathrm{N}$-formyl-conessimine (1) and conimine (2), isolated from the seeds of $H$. antidysenteriaca, were proved to be potential anti-MRSA activity with minimum inhibitory concentration (MIC) of $128 \mu \mathrm{g} / \mathrm{mL}$ and possessed synergistic effects with penicillin and vancomycin. In another study, bioassay guided fractionation and purification of the extract from Hypericum riparium leaves resulted in the isolation
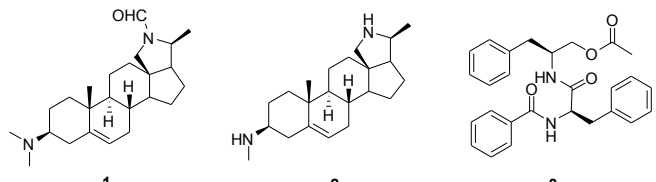

3

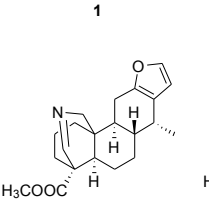

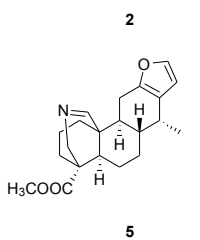<smiles>CC(C)=CCNC(=N)N</smiles><smiles>CC(C)=CCNC(=N)NC=CC(C)C</smiles>

5

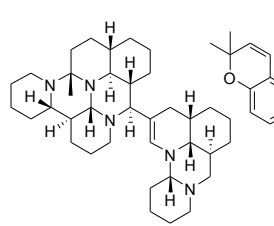

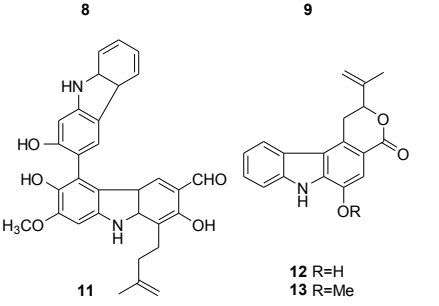

10

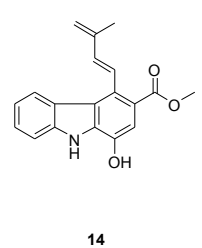

Figure 1 The structures of compounds 1-14.

of aurentiamide acetate (3) with significant antimicrobial potential $\left(\mathrm{IC}_{50}=6.54 \mu \mathrm{M}\right)$ on S. aureus. ${ }^{[7]}$ In 2013 , Liu et al. found that Traditional Chinese Medicines (TCMs) Caesalpinia sappan exhibited good activity against MRSA with MIC of $12.5 \mu \mathrm{g} / \mathrm{mL}$. Further research resulted in the isolation of two active compounds, caesanines $A(4)$ and $B(5)$, with activities against MRSA in a range of MIC values between 3.125 and 12.5 $\mu \mathrm{g} / \mathrm{mL} .^{[8]}$ Galegine (6) and pterogynidine (7), rarely occur in plants, belonging to the guanidine alkaloids, showed MIC value 
of $4 \mathrm{mg} / \mathrm{L}$ to all tested MRSA strains. The preliminary chemical features correlating to anti-MRSA activity showed that the size of the side chain and the substitution pattern in the guanidine core played a key role in the antibacterial activity of the imino group. ${ }^{[9]}$ Myrifabine (8), the first example of a dimer with 12 chiral centers embraced in a decacyclic novel skeleton, isolated from Myrioneuron faberi by Hao et al., was evaluated. It showed moderate activities against $S$. aureus (ATCC25913) and methicillin-resistant $S$. aureus (MRSA082 and MRSA098), with MIC values ranging from 6.32 to $25.07 \mu \mathrm{g} / \mathrm{mL} .^{[10]}$ The Clausena genus of the Rutaceae family is known to produce carbazole alkaloids that possess antibacterial activities. Compounds clausenawallines E (9), 2,7-dihydroxy-3-form- yl-1-(3'methyl-2'-butenyl) carbazole (10) and clausenawalline B (11) were isolated from the roots of $C$. wallichii, which exhibited significant antibacterial activity against MRSA SK1 with MIC values in the range of $4-16 \mu \mathrm{g} / \mathrm{mL} .^{[11]}$ In addition, three alkaloids, clausamine A (12), clausamine $B(13)$ and clausine $F(14)$, were isolated from the twigs of other genus $C$. harmandiana by Laphookhieo et al. Compound 12 exhibited significant antibacterial activity against MRSA SK1 with an MIC value of 0.25 $\mu \mathrm{g} / \mathrm{mL}$ which was higher than that of standard drug, vancomycin ( $\mathrm{MIC}=1 \mu \mathrm{g} / \mathrm{mL})$. Compounds 13 and 14 also showed strong activity against MRSA SK1 with MIC values of 8 and $4 \mu \mathrm{g} / \mathrm{mL}$, respectively. ${ }^{[12]}$

\section{Flavonoids}

Flavonoids are a large group of compounds found in plants. Many of them have been reported possessing anti-MRSA activity (Figure 2).
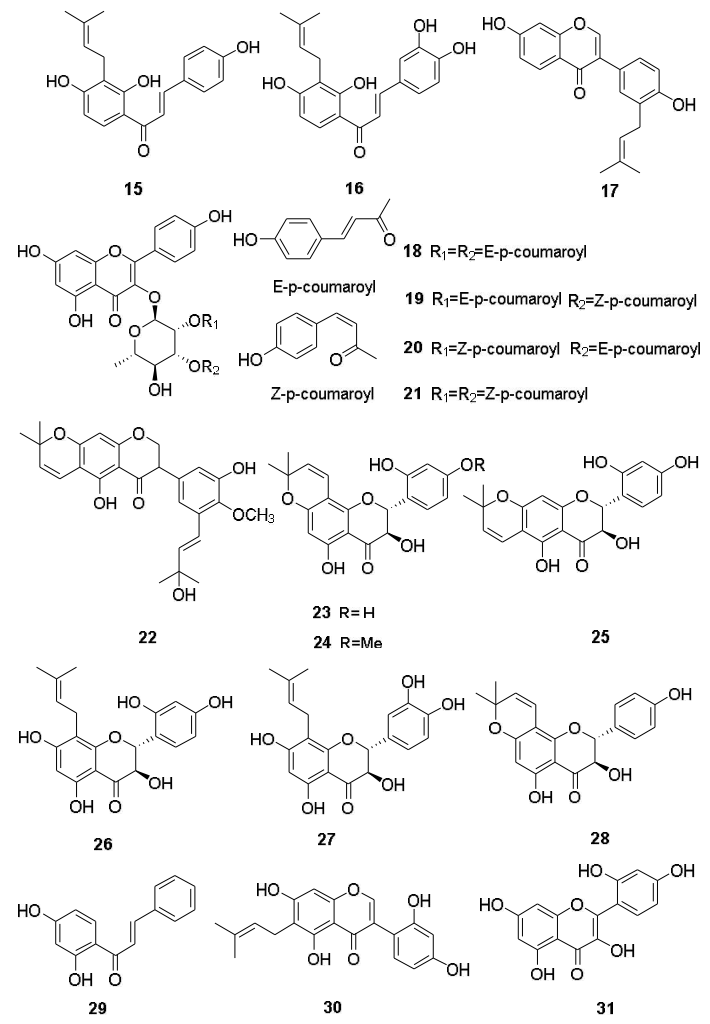

Figure 2 The structures of compounds 15-31.

Hatano et al. reported that flavonoids (the main constituent of the fruits of Psoralea corylifolia) exhibited remarkable anti-MRSA effects. Further research showed isobavachalcone (15), corylifol $B(16)$ and neobavaisoflavone (17) showed significant anti-MRSA effects (MIC $=8,16,16 \mu \mathrm{g} / \mathrm{mL}$, respective- ly). ${ }^{[13]}$ The leaves extract of Platanus occidentalis also exhibited potent anti-MRSA activity. Bioassay guided extraction of $P$. occidentalis was performed and led to four flavonoids, kaempferol 3-O- $\alpha-L-\left(2^{\prime \prime}, 3^{\prime \prime}-\mathrm{di}-E-p\right.$-coumaroyl) rhamnoside (18) $\left(\mathrm{IC}_{50}=2.0 \mu \mathrm{g} / \mathrm{mL}\right)$, kaempferol 3-O- $\alpha-L-\left(2^{\prime \prime}-E-p\right.$-coumaroyl3"'-Z-p-coumaroyl) rhamnoside (19) $\left(\mathrm{IC}_{50}=0.8 \mu \mathrm{g} / \mathrm{mL}\right)$, kaempferol 3-O- $\alpha-L-\left(2^{\prime \prime}-Z-p\right.$-coumaroyl-3"'-E-p-coumaroyl) rhamnoside (20) $\left(\mathrm{IC}_{50}=0.7 \mu \mathrm{g} / \mathrm{mL}\right)$, and kaempferol 3-O- $\alpha-L$ (2", 3"'-di-Z-p-coumaroyl) rhamnoside (21) $\left(\mathrm{IC}_{50}=0.4 \mu \mathrm{g} / \mathrm{mL}\right)$. The structure-activity relationship of the isolates showed that the presence of the flavonoid moiety connected to the $p$-coumaroyl functionality through the sugar and the presence of hydroxy groups at positions 5, 7, and $4^{\prime}$ were important for the anti-MRSA activity. ${ }^{[14]}$ 5,3'-Dihydroxy-5'-(3- hydroxy-3- methyl-1-butenyl)-4'-methoxy-2"'-2"'-dimethylpyrano[5,6:6,7]isoflavanone (22) isolated from the stems of Erythrina costaricensis exhibited a weak anti-MRSA activity $\left(\mathrm{MIC}_{50}=25\right.$ $\mu \mathrm{g} / \mathrm{mL}$ ). Further related research showed the presence and position of the prenyl group in the isoflavanones may play an important role in the anti-MRSA activity. ${ }^{[15]}$ Kashiwada et al. isolated flavonoids from roots of Desmodium caudatum and tested their anti-MRSA activity. The isolated compounds 22-25 displayed relatively potent inhibitory activity against MRSA with MIC values ranging from 15.6 to $31.3 \mu \mathrm{g} / \mathrm{mL}$. In addition, compounds sophoraflavanone B (26), 8- $(\gamma, \gamma$-dimethylallyl)$5,7,4^{\prime}$-trihydroxydihydroflavonol (27) and yukovanol (28) also showed strong inhibitory effects on it. ${ }^{[16]}$ Bioassay-guided screening resulted in the isolation of compound $2^{\prime}, 4^{\prime}$-dihydroxychalcone (29) by Ahmat et al., which exhibited the antibacterial activity with MIC value of $100 \mu \mathrm{g} / \mathrm{mL}$ against MRSA. ${ }^{[17]}$ Luteone (30), isolated from the bark of Erythrina stricta, exhibited significant antibacterial activity with minimum inhibitory quantity (MIQ) values of $1.88,1.88$ and $3.75 \mu \mathrm{g}$, respectively, agains MRSA. ${ }^{[18]}$ Morin (31), a plant-derived flavonol, in combination with $\beta$-lactam antibiotics can remarkably suppressed the growth of MRSA. The drastic reduction in the cell viability test showed that the combination of antibiotics and compound $\mathbf{3 1}$ can obviously reverse the $\beta$-lactam antibiotic resistance in a MRSA. ${ }^{[19]}$

\section{Terpenoids}

Terpenoids are derived from five-carbon isoprene unites and they represent a large class of natural compounds. Monoterpenes are often found in the essential oils extracted from many plants. Most of monoterpenes have characteristic smell and antimicrobial activity. A natural sesquiterpenoid, $1 \alpha, 6 \beta$-dimethyl- $5 \beta$-hydroxy- $4 \beta$-(prop-1-en-2-yl)-decahydronaphthalen-2-one (32), displayed moderate anti-MRSA $\left(\mathrm{IC}_{50}=\right.$ $8.5 \mu \mathrm{g} / \mathrm{mL}$ ) isolated from the chloroformic extract of Mentha pulegium by Ibrahim. ${ }^{[20]}$ Acanthospermal B (33), the major sesquiterpene lactone from Acanthospermum hispidum, is a selective antibacterial agent against MRSA, which displayed a bacteriostatic effect, in vitro and in vivo. In addition, Acanthospermal B (33) exhibited a strong liver protective effect in MRSA acute infections and produced a significant decrease in chronic skin MRSA infections. ${ }^{[21]}$ Compadre et al. found dehydroleucodine (34), extracted and purified from the aerial parts of Gynoxys verrucosa, has moderate activity with $\mathrm{MIC}_{50}$ between 49 and $195 \mu \mathrm{g} / \mathrm{mL}$ and $280-680 \mu \mathrm{g} / \mathrm{mL}$ for the $\mathrm{MIC}_{90}$, suggesting its potential use as a template for further development. ${ }^{[22]}$ Caesalfurfuric acid A (35), one isopimarane diterpene, isolated from the twigs of Caesalpinia furfuracea, was found to exhibit moderate antibacterial activity against MRSA SK1 with the MIC value of $16 \mu \mathrm{g} / \mathrm{mL} .{ }^{[23]}$ Bioassay guided isolation of the ethyl acetate fraction of Siegesbeckia orientalis led to the isolation of ent-kaurane diterpenoids, $16 \beta$-hydro-ent-kauran-17,19- 
Medicine Research

dioic acid (36), 16 $\alpha, 17$-dihydroxy-ent-kauran-19-oic acid (37), $16 \beta, 17,18$-trihydroxy-ent-kauran-19-oic acid (38), and 17,18dihydroxy-ent-kauran-19-oic acid (39), which all exhibited the anti-MRSA activity with MIC valuses of in the range of $0.05-0.50 \mathrm{mg} / \mathrm{mL} .{ }^{[24]}$ Two abietane diterpenes compounds, $2 \beta$-ace toxyferruginol (40) and ferruginol (41), isolated from the stem bark of Prumnopitys andina also exhibited antibacterial activity at $8 \mu \mathrm{g} / \mathrm{mL}$ against two effluxing strains of $S$. aureus. ${ }^{[25]}$ Two 29-nor-cycloart triterpenoids, aphagrandinoids $A(42)$ and

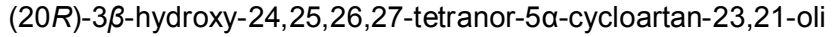
de (43) were isolated from the leaves and twigs of Aphanamixis grandifolia. These compounds were proved to be potent antibacterial activities (MIC values: $1.57-3.13 \mu \mathrm{g} / \mathrm{mL}$ ) against MRSA $92^{\#}$, MRSA $98^{\#}$, and S. aureus. ${ }^{[26]}$ Bioassay guided fractionation of the roots of Lantana montevidensis resulted in the isolation of triterpenoids $12 \beta, 13 \beta$-dihydroxyolean-3-oxo-28-oic acid (44) and camaric acid (45). Compound 45 showed potent activity against $S$. aureus and MRSA with $\mathrm{IC}_{50}$ values of 8.74 and $8.09 \mu \mathrm{M}$, respectively, while compound 44 showed even better activity with $\mathrm{IC}_{50}$ values of $2.1 \mu \mathrm{M}$ against both organisms (Figure 3). ${ }^{[27]}$
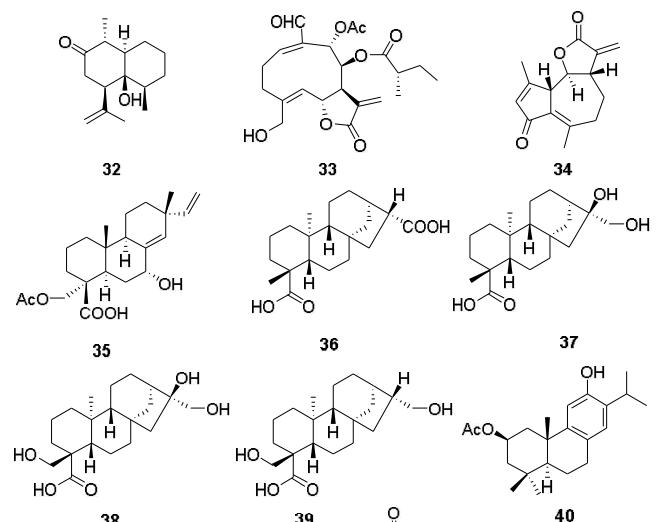

36

37

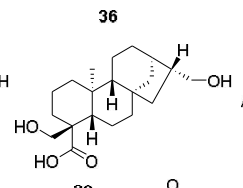

39

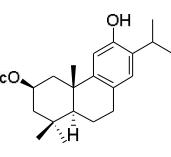<smiles>CC(C)c1cc2c(cc1O)C1(C)CCCC(C)C1CC2</smiles>

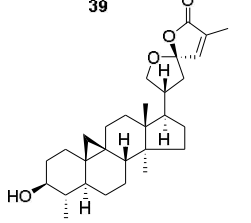

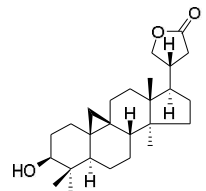

43

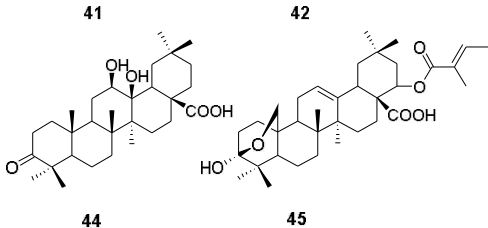

45

Figure 3 The structures of compounds $32-45$

\section{Coumarins}

Coumarins are an important class of natural polyphenolic compounds which belong to the benzopyrones family. From the bioactivity-guided fractionation of the extracts prepared from the Chinese medicinal plant Zanthoxylum nitidum, Zuo et al. found the four plant coumarins 5-geranyloxy-7-methoxycoumarin (46), (5,7-dimethoxy-8- prenyloxycoumarin (47), isopimpinellin (48) and phellopterin (49), isolated and identified from $Z$. nitidum extracts, displayed promising inhibition against MRSA with MICs of 8-64 $\mu \mathrm{g} / \mathrm{mL}$ (Figure 4). ${ }^{[28]}$

\section{Anthraquinones}

Anthraquinones are a class of natural compounds that consist of several hundred compounds that differ in the nature

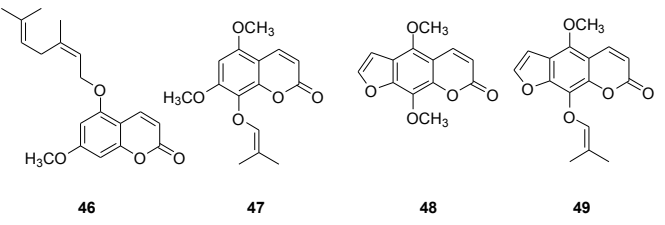

Figure 4 The structures of compounds 46-49.

and positions of substituent groups. Bioassay guided fractionation of the ethanolic extract of Asphodelus microcarpus resulted in the isolation of three active compounds, Asphodosides B-D (50-52) exhibiting activity against MRSA with $I_{50}$ values of 1.62, 7.0 and $9.0 \mu \mathrm{g} / \mathrm{mL}$, respectively. ${ }^{[29]}$ Emodin (53), purified from the extract of Hypericum riparium leaves also showed significant antimicrobial potential $\left(\mathrm{IC}_{50}=11.71 \mu \mathrm{g} / \mathrm{mL}\right)$ against MRSA. Further research revealed that compound $\mathbf{5 3}$ could damage the integrity of cell wall, leading to loss of intracellular components (Figure 5). ${ }^{[7,30]}$

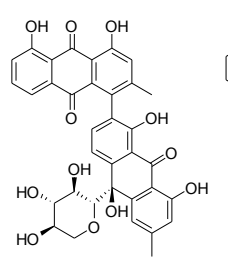

50

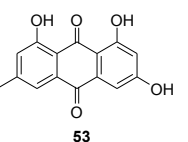

Figure 5 The structures of compounds 50-53.

\section{Xanthones}

Natural xanthones constitute an important class of oxygenated heterocycles, occurring as secondary metabolites in plants. The genus Garcinia dulcis are rich in xanthones. $12 \mathrm{~b}-\mathrm{Hydroxy}$-des- $D$-garci- gerrin $\mathrm{A}(\mathbf{5 4})$ and dulcisxanthone $J$ (55) were isolated by Mahabusarakam et al. exhibiting moderate antibacterial activity against both penicillin-susceptible Staphylococcus aureus and MRSA with MIC values of 4 and 16 $\mu \mathrm{g} / \mathrm{mL}$, respectively. ${ }^{[31]}$ Phytochemical investigation of the other genus Garcinia propinqua led to the isolation and identification of compounds 10-O-methylmacluraxanthone (56) and macluraxanthone (57), which showed good activity against MRSA SK1 and S. aureus TISTR 1466, with MIC values in the range $2-4 \mu \mathrm{g} / \mathrm{mL} .{ }^{[32]}$ Tala et al. found 1,5-dihydroxy-2-methoxyxynthone (58) showed activity against MRSA with $\mathrm{IC}_{50}$ value of $18.5 \mu \mathrm{g} / \mathrm{mL}$ (Figure 6 ). ${ }^{[7]}$
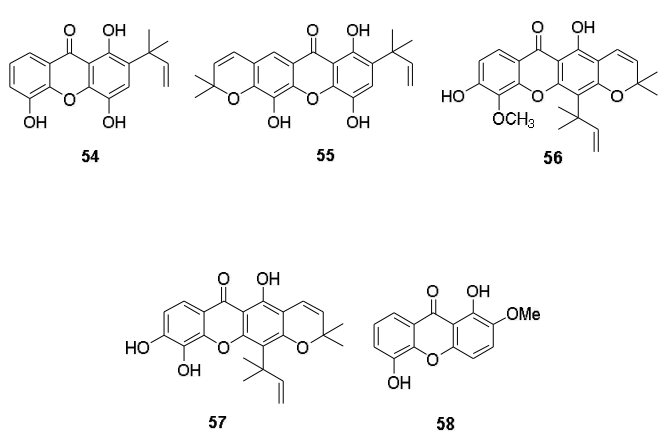

Figure 6 The structures of compounds 54-58. 


\section{Minireview}

\section{Lignans}

Four lignans, manglisins A-D (59-62), isolated from the mature carpels of Manglietiastrum sinicum, exhibited moderate antimicrobial activities (MIC values: $0.016-0.14 \mu \mathrm{M}$ ) against MRSA 82\#, MRSA 92\#, MRSA 98\#, and MRSA 331". ${ }^{\text {[33] Two }}$ neolignans, callislignan $A(63)$ and $B(64)$, were isolated from the leaves of Callistemon lanceolatus with antibacterial activity against S. aureus ATCC25923 and MRSA SK1. Callislignan B (64) exhibited the best activity with MIC value of $8 \mu \mathrm{g} / \mathrm{mL}^{[34]}$ The genus Piper regnellii is a medicinal plant traditionally used in Brazil to treat infectious diseases. The extracts of the leaves from $P$. regnellii were investigated for their antibacterial activities against MRSA and afforded the pure compound eupomatenoid-5 (65). Compound 65 inhibited the growth of MRSA with MICs $1-8 \mu \mathrm{g} / \mathrm{mL}$ (Figure 7 ). ${ }^{[35]}$
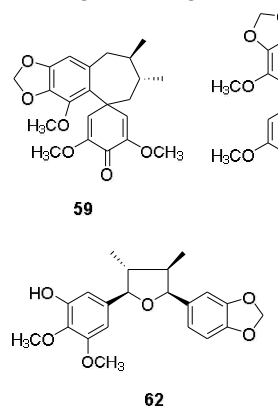

62

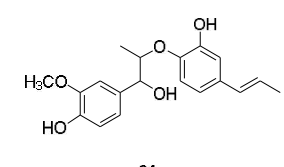

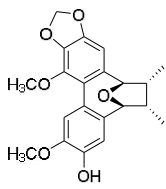
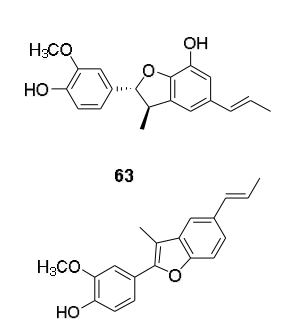

65
Figure 7 The structures of compounds 59-65.

\section{Phenolics}

Phenolics are effective against pathogenic bacteria including MRSA. A chloroform-soluble extract of Mallotus philippensis was subjected to bioassay-guided fractionation using chromatographic and spectrometric techniques that led to the isolation of two compounds, rottlerin (66) and 8-cinnamoyl-5,7-dihydroxy-2,2,6-trime thylchromene (67), which showed potent activities against MRSA. ${ }^{[36]}$ Two antibacterial compounds, 23-methyl-6-O-desmethylauricepy- rone (68) and (Z,Z)-5-(trideca-4,7dienyl)-resorcinol (69) were isolated from the ethanol extracts of Achyrocline satureioides and Lithrea molleoides, respectively. Compound 68 showed MIC value of $2 \mu \mathrm{g} / \mathrm{mL}$ against strains of $S$. aureus, while compound 69 exhibited anti-MRSA activity with MIC value of $2 \mu \mathrm{g} / \mathrm{mL} .{ }^{[37]}$ Four pterocarpans, erybraedin $A(70)$, erythrabyssin II (71), erystagallin A (72), and erycristagallin (73) were isolated from the stems of Erythrina subumbrans. Compounds 71 and $\mathbf{7 3}$ exhibited the highest degree of activity against Streptococcus strains with MICs in range of 0.78-1.56 $\mu \mathrm{g} / \mathrm{mL}$, whereas compound 73 not only exhibited the highest degree of activity against Staphylococcus strains, but also showed anti- MRSA activity, with MICs in range of 0.39-1.56 $\mu \mathrm{g} / \mathrm{mL} .^{[38]}$ Two new oxygen heterocyclic Diels-Alder-type adducts, sorocenols $G(\mathbf{7 4})$ and $H(\mathbf{7 5})$, isolated and identified from a root extract of Sorocea muriculata using bioassay-guided method showed significant and selective activity against MRSA with $\mathrm{IC}_{50}$ values of 1.5 and $0.5 \mu \mathrm{M}$, respectively. ${ }^{[39]}$ Bioassay guided fractionation and purification of the extract from Hypericum riparium leaves resulted in the isolation of compounds chipericumin $E(\mathbf{7 6})$ and hypercalin $C(\mathbf{7 7})$, which showed significant antimicrobial potential $\left(6.54 \mu \mathrm{g} / \mathrm{mL} \leq \mathrm{IC}_{50} \leq\right.$ $16.90 \mu \mathrm{g} / \mathrm{mL}$ ) against MRSA (Figure 8 ). ${ }^{[7]}$

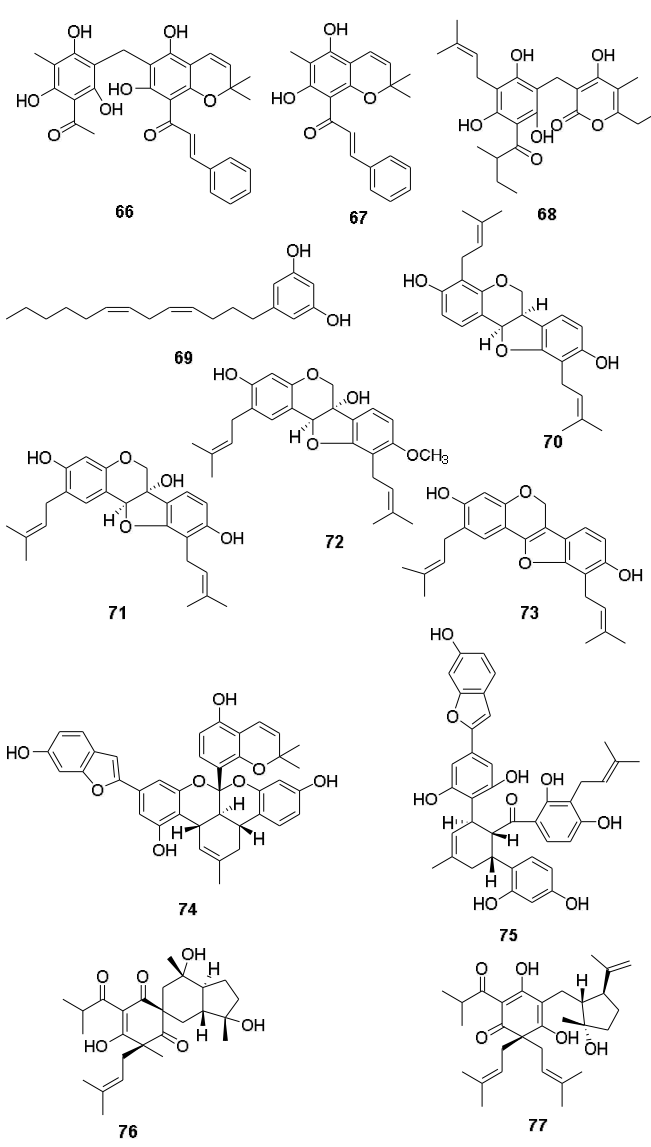

Figure 8 The structures of compounds 66-77.

\section{Others}

Vasas et al. investigated the anti-MRSA activity of the genera Juncus belonging to the family Juncaceae and found that the species J. maritimus, J. tenuis and J. gerardii were w orthy of activity-guided phytochemical investigations. Four phenanthrenes, juncuenin $D(\mathbf{7 8})$, juncusol (79), dehydro- juncuenin $B$ $(\mathbf{8 0})$, and jinflexin $B(\mathbf{8 1})$ were proved to be active in antimicrobial test. ${ }^{[40]}$ Compound $\mathbf{8 2},(6 E, 12 E)$-tetrade-cadiene-8,10diyne-1,3-diol, isolated from the $\mathrm{CHCl}_{3}$-soluble extract of roots of Atractylodes japonica showed anti-MRSA activity with MIC values of $4-32 \mu \mathrm{g} / \mathrm{mL}$. The results provide promising information for the potential use of the extract of $A$. japonica in the treatment of bacterial infections (Figure 9 ). ${ }^{[41]}$

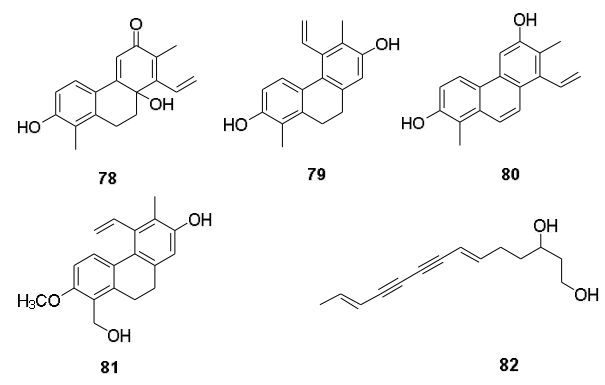

Figure 9 The structures of compounds 78-82.

\section{Conclusions and Outlook}

There is no doubt that (multiple) antibiotic resistance of bacteria (such as MRSA) is a significant problem in public health. The development of new antibacterial agents is important and plant derived compounds are an attractive source 
for new drugs because of their diversity and unusual structure. Some plant derived compounds not only have direct anti-MRSA activity but also have the synergistic effect with conventional antibiotics, which could provide effective activity against MRSA. However, despite the large number of studies dealing with the investigation of plant derived compounds on MRSA, there is a huge gap to be using as clinical practice because of the deficiency of in vivo and clinical studies. In conclusion, this review summarized the literatures spanning 2007 to 2017 results and emphasized the potential of anti-MRSA plant derived products to be a promising solution to control the antibiotic resistance problem.

\section{Acknowledgement}

This work was supported by the National Natural Science Foundation of China (No. 81673322) and the Key Scientific Research Project in University of Henan Province (No. 17A350013).

\section{References}

[1] Guignard, B.; Entenza, J. M.; Moreillon, P. Curr. Opin. Pharmacol. 2005, 5, 479.

[2] Park, J. Y.; Jin, J. S.; Kang, H. Y.; Jeong, E. H.; Lee, J. C.; Lee, Y. C.; Seol, S. Y.; Cho, D. T.; Kim, J. J. Microbiol. 2007, 45, 447

[3] Kardos, N.; Demain, A. L. Appl. Microbiol. Biotechnol. 2011, 92, 677.

[4] David, M. Z.; Daum R. S. Clin. Microbiol. Rev. 2010, 23, 616.

[5] Nannini, E.; Murray B. E.; Arias, C. A. Curr. Opin. Pharmacol. 2010, 10, 516.

[6] Zhou, L. N.; Ge, X. L.; Dong, T. T.; Gao, H. Y.; Sun, B. H. Chin. J. Nat. Med. 2017, 15, 540.

[7] Tala, M. F.; Talontsi, F. M.; Zeng, G. Z.; Wabo, H. K.; Tan, N. H.; Spiteller, M.; Tane, P. Fitoterapia 2015, 102, 149.

[8] Zhang, J. Y.; Abdel-Mageed, W. M.; Liu, M. M.; Huang, P.; He, W. N.; Li, L.; Song, F. H.; Dai, H. Q.; Liu, X. T.; Liang, J. Y.; Zhang, L. X. Org. Lett. 2013, 15, 4726.

[9] Coqueiro, A.; Regasini, L. O.; Stapleton, P.; Bolzani, V. D. S.; Gibbons, S. J. Nat. Prod. 2014, 77, 1972.

[10] Cao, M. M.; Huang, S. D.; Di, Y. T.; Yuan, C. M.; Zuo, G. Y.; Gu, Y. C.; Zhang, Y.; Hao, X.J. Org. Lett. 2014, 16, 528.

[11] Maneerat, W.; Ritthiwigrom, T.; Cheenpracha, S.; Promgool, T.; Yossathera, K.; Deachathai, S.; Phakhodee, W.; Laphookhieo, S. J. Nat. Prod. 2012, 75, 741.

[12] Maneerat, W.; Phakhodee, W.; Ritthiwigrom, T.; Cheenpracha, S.; Promgool, T.; Yossathera, K.; Deachathai, S.; Laphookhieo, S. Fitoterapia 2012, 83, 1110.

[13] Cui, Y. M.; Taniguchi, S.; Kuroda, T.; Hatano, T. Molecules 2015, 20, 12500.

[14] Ibrahim, M. A.; Mansoor, A. A.; Gross, A.; Ashfaq, M. K.; Jacob, M.; Khan, S. I.; Hamann, M. T. J. Nat. Prod. 2009, 72, 2141.

[15] Tanaka, H.; Hattori, H.; Oh-Uchi, T.; Sato, M.; Yamaguchi, R.; Sako, M.; Tateishi, Y. J. Asian Nat. Prod. Res. 2008, 10, 983.

[16] Sasaki, H.; Kashiwada, Y.; Shibata, H.; Takaishi, Y. Phytochemistry 2012, 82, 136.

[17] Sufian, A. S.; Ramasamy, K.; Ahmat, N.; Zakaria, Z.A.; Yusof, M. I. M. J. Ethnopharmacol. 2013, 146, 198.

[18] Akter, K.; Barnes, E. C.; Loa-Kum-Cheung, W. L.; Yin, P.; Kichu, M.; Brophy, J. J.; Barrow, R. A.; Imchen, I.; Vemulpad, S. R.; Jamie, J. F. J. Ethnopharmacol. 2016,
185,171

[19] Mun, S. H.; Lee, Y. S.; Han, S. H.; Lee, S. W.; Cha, S. W.; Kim, S. B.; Seo, Y. S.; Kong, R.; Kang, D. H.; Shin, D. W.; Kang, O. H.; Kwon, D. Y. Foodborne Pathog. Dis. 2015, 12, 545.

[20] Ibrahim, A. K. Nat. Prod. Res. 2013, 27, 691.

[21] Arena, M. E.; Cartagena, E.; Gobbato, N.; Baigori, M.; Valdez, J. C.; Bardon, A. Phytother. Res. 2011, 25, 597.

[22] Ordónez, P. E.; Quave, C. L.; Reynolds, W. F.; Varughese, K. I.; Berry, B. Breen, P. J.; Malagón, O.; Smeltzer, M. S.; Compadre, C. M. J. Ethnopharmacol. 2011, 137, 1055.

[23] Siridechakorn, I.; Cheenpracha, S.; Ritthiwigrom, T.; Phakhodee, W.; Deachathai, S.; Machan, T.; Ruankeaw, N.; Laphookhieo, S. Phytochem. Lett. 2014, 7, 186.

[24] Yang, Y.; Chen, H.; Lei, J. C.; Yu, J. Q. Ind. Crop. Prod. 2016, 94, 288.

[25] Smith, E. C. J.; Wareham, N.; Zloh, M.; Gibbons, S. Phytochem. Lett. 2008, 1, 49.

[26] Wang, X. Y.; Tang, G. H.; Yuan, C. M.; Zhang, Y.; Zou, T.; Yu, C.; Zhao, Q.; Hao, X. J.; He, H. P. Fitoterapia 2013, 85, 64.

[27] Mohamed, N. M.; Makboul, M. A.; Farag, S. F.; Jain, S.; Jacob, M. R.; Tekwani, B. L.; Ross, S. A. Phytochem. Lett. 2016, 15, 30

[28] Zuo, G. Y.; Wang, C. J.; Han, J.; Li, Y. Q.; Wang, G. C. Phytomedicine 2016, 23, 1814.

[29] Ghoneim, M.M.; Elokely, K.M.; El-Hela, A.A.; Mohammad, A.I.; Jacob, M.; Radwan, M.M.; Doerksen, R.J.; Cutler, S.J.; Ross, S.A. Phytochemistry 2014, 105, 79.

[30] Cao, F.; Peng, W.; Li, X. L.; Liu, M.; Li, B.; Qin, R. X.; Jiang, W. W.; Cen, Y. Y.; Pan, X. C.; Yan, Z. F.; Xiao, K. K.; Zhou, H. Can. J. Physiol. Pharmacol. 2015, 93, 1.

[31] Thepthong, P.; Phongpaichit, S.; Carrolld, A. R.; Voravuthikunchai, S. P.; Mahabusarakam W. Phytochem. Lett. 2017, 21, 32.

[32] Tantapakul, C.; Phakhodee, W.; Ritthiwigrom, T.; Cheenpracha, S.; Prawat, U.; Deachathai, S.; Laphookhieo, S. J. Nat. Prod. 2012, 75, 1660.

[33] Ding, J. Y.; Yuan, C. M.; Cao, M. M.; Liu, W. W.; Yu, C.; Zhang, H. Y.; Zhang, Y.; Di, Y. T.; He, H. P.; Li, S.L.; Hao, X. J. J. Nat. Prod. 2014, 77, 1800.

[34] Rattanaburi, S.; Mahabusarakam, W.; Phongpaichit, S.; Carroll, A. R. Phytochem. Lett. 2012, 5, 18.

[35] Marçal, F. J. B.; Cortez, D. A. G.; Ueda-Nakamura, T.; Nakamura, C. V.; Filho, B. P. D. Molecules 2010, 15, 2060.

[36] Oyedemi, B. O. M.; Shinde, V.; Shinde, K.; Kakalou, D.; Stapleton, P. D.; Gibbons, S. J. Glob. Antimicrob. Re. 2016, $5,15$.

[37] Joray, M. B.; González, M. L.; Palacios, S. M.; Carpinella, M. C. J. Agr. Food Chem. 2011, 59, 11534.

[38] Rukachaisirikul, T.; Innok, P.; Aroonrerk, N.; Boonamnuaylap, W.; Limrangsun, S.; Boonyon, C.; Woonjina, U.; Suksamrarn, A. J. Ethnopharmacol. 2007, 110, 171.

[39] Ross, S. A.; Rodríguez-Guzmán, R.; Radwan, M. M.; Jacob, M.; Ding, Y. Q.; Li, X. C.; Ferreira, D.; Manly, S. P. J. Nat. Prod. 2008, 71, 1764.

[40] Tóth, B.; Liktor-Busa, E.; Urbán, E.; Csorba, A.; Jakab, G.; Hohmann, J.; Vasas, A. Fitoterapia 2016, 115, 69.

[41] Jeong, S. I.; Kim, S. Y.; Kim, S. J.; Hwang, B. S.; Kwon, T. H.; Yu, K. Y.; Hang, S. H.; Suzuki, K.; Kim, K. J. Molecules 2010, 15, 7395.

Received September 28, 2017 Accepted November 3, 2017 